\title{
Enhancing productivity for inclusive growth
}

Last update: 13 March 2017

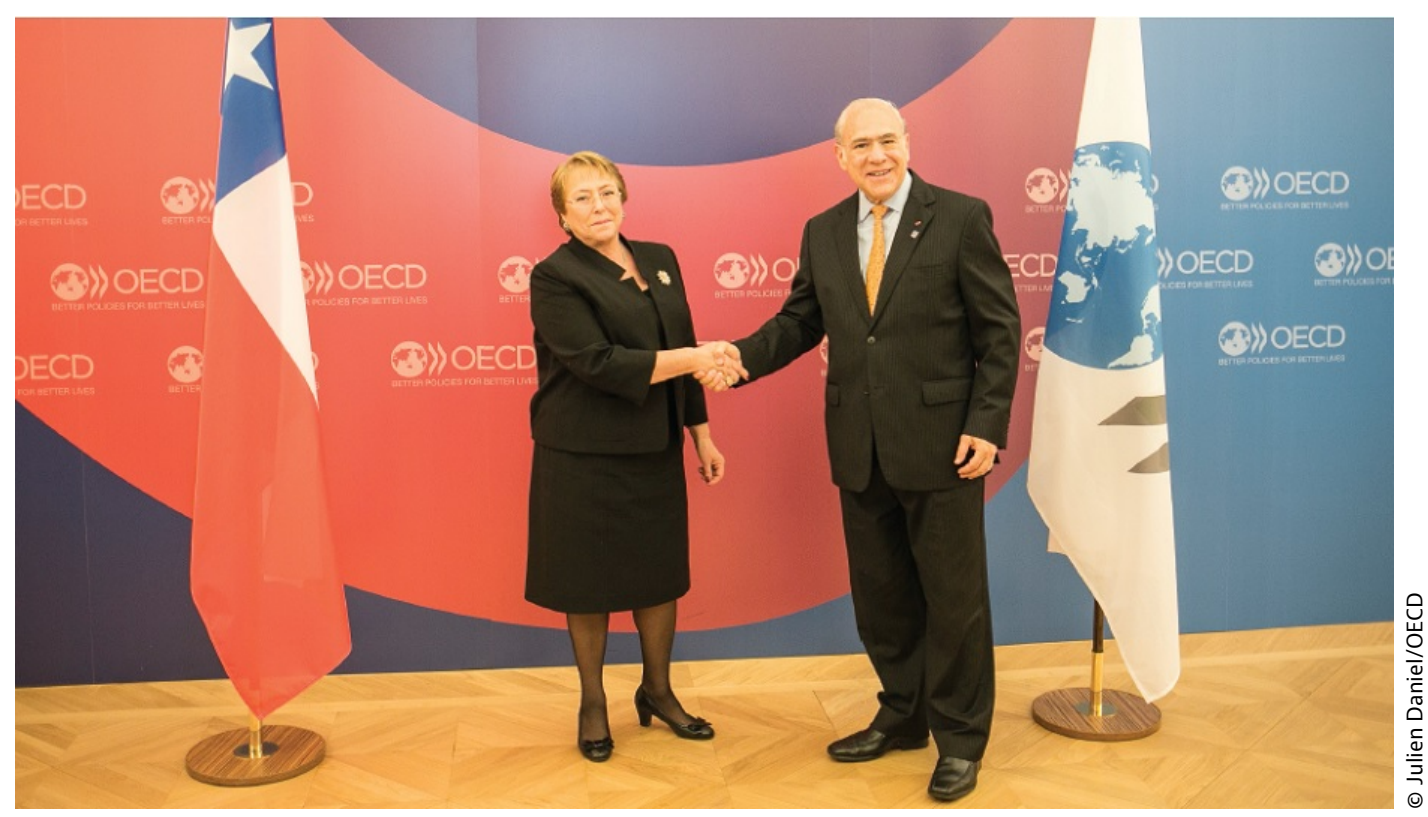

President Michelle Bachelet of Chile and OECD Secretary-

General Angel Gurría

The 2016 OECD Ministerial Council Meeting (MCM) was held at the OECD headquarters in Paris on Wednesday and Thursday 1-2 June 2016, back to back with the OECD Forum, which started on 31 May.

The MCM took place under the chairmanship of Chile, with Finland, Hungary and Japan as vice-chairs. The meeting brought together OECD member and partner countries, to explore policies that respond to productivity growth and inclusion goals in mutually reinforcing ways. In a global economic context of slow growth, weak trade and investment, and persistently high unemployment, the ministers called on the OECD to explore policy solutions for enhancing productivity while fostering inclusive growth.

Special attention was paid to how to achieve higher productivity and enhance inclusiveness, at the individual (or household), firm, regional and country level. Ministers also discussed the economic outlook, the strategic orientations of the OECD Secretary-General, how to help achieve the UN Sustainable Development 
Goals and how to strengthen the contribution of trade and investment to productivity and inclusive growth, while making further progress on Responsible Business Conduct standards. They also discussed the future of work in response to digitalisation and rapid technological change and preparing for the Next Production Revolution.

This year's MCM marked the accession of Latvia as the organisation's 35th member country, and the launch of the OECD Latin America and Caribbean Regional Programme (see http://oe.cd/1AV). Ministers commended the progress made by Colombia, Costa Rica and Lithuania in their ongoing accession processes. They welcomed the OECD's strong collaboration with the G7, G20, APEC, and the Pacific Alliance, and called on the OECD to advance further its work on the international governance architecture, and its work with emerging and developing countries, to raise the global visibility and impact of the OECD's work and standards. Ministers agreed on the value of the OECD's global reach and called for a strategic reflection by the OECD on its future size and membership.

\section{References}

Chair's summary http://oe.cd/1wo

Ministerial Council Statement http://oe.cd/1wp

Strategic Orientations of the Secretary-General http://oe.cd/1wr

Declaration on Enhancing Productivity for Inclusive Growth http://oe.cd/1wq

The Productivity-Inclusiveness Nexus http://oe.cd/1ws

Other reports from the 2016 meeting, and from annual Ministerial Council Meetings held since 2009, are available at www.oecd.org/mcm/documents (scroll to bottom).

Communiqués from 1976 to 2008 are available at www.g8.utoronto.ca/oecd/ index.html

For all archives, contact Library\&Archives@oecd.org 